\title{
Microbial Load on Smoked Fish commonly traded in Ibadan, Oyo State, Nigeria
}

\section{1*AYELOJA, AA; ${ }^{2}$ GEORGE, FOA; ${ }^{1} \mathrm{JIMOH}, \mathrm{WA} ;{ }^{3} \mathrm{SHITTU}, \mathrm{MO} ;{ }^{4}$ ABDULSALAMI, S A}

\author{
${ }^{I}$ Department of Aquaculture and Fisheries, University of Ilorin, PMB 1515 Ilorin, Kwara State, Nigeria \\ ${ }^{2}$ Department of Aquaculture and Fisheries Management, Federal University of Agriculture, Abeokuta, Nigeria \\ ${ }^{3}$ Department of Fisheries Technology, Federal College of Animal Health and Production Technology Moor Plantation, Ibadan, Nigeria \\ ${ }^{4}$ Department of Biological Sciences, Aquaculture and Fisheries Unit, Crescent University, PMB 2104, Sapon Abeokuta, Ogun State, Nigeria \\ *Corresponding E-mail: ayeloja2@gmail.com,aye_ayo@yahoo.com
}

\begin{abstract}
The microbial load on smoked fish sold in Ibadan, Oyo State was studied. 64 of 4 different fish species (Mackerel (Scomber scombrus), Sardine (Sardinela eba), Panla (Gadus morhua) and Cat fish (Clarias gariepinus)) were sourced from five different market locations. The microbiological analysis was done using standard microbiological procedures. The bacterial count of fish sampled from Ojo market was the highest $\left(0.35 \pm 0.11 \times 10^{3} \mathrm{CFU} / \mathrm{g}\right)$ while the bacteria count of the fish sample from Bodija market was the lowest $\left(0.07 \pm 0.04 \times 10^{3} \mathrm{CFU} / \mathrm{g}\right)$. There was no significant difference $(\mathrm{p}>0.05)$ in the microbial load of the various fish species sold within Ibadan metropolis as well as fish sampled from various market locations in Ibadan metropolis. Bacterial isolated on smoked fish studied were: E. coli, Salmonella spp, Klebsiella spp, Staphylococcus aureus, Aerosomonas spp, Pseudomonas spp, Vibrio spp, Serratia spp, Chromobacterium spp, Enterobacteria spp and Shigella spp. While the following fungi were isolated from the study: Aspergillus flavus, Penicillium spp, Fusarium oxysporum, Trrichoderma spp and Ceotrichium albidium. Fish species sold in different markets within Ibadan metropolis is fit for human consumption. Caution should be exercised in consuming smoked-dried fish displayed openly, reheating may be necessary to activate such micro-organisms before consumption.
\end{abstract}

DOI: https://dx.doi.org/10.4314/jasem.v22i4.9

Copyright: Copyright $(92018$ Ayeloja et al. This is an open access article distributed under the Creative Commons Attribution License (CCL), which permits unrestricted use, distribution, and reproduction in any medium, provided the original work is properly cited.

Dates: Received: 17 March 2018; Revised: 07 April: 2018; Accepted: 09 April 2018

Keywords: bacteria, fungi, market, fish species

Consumption of fish and fish products is recommended due to good digestibility and the high content of polyunsaturated fatty acids. Fishes are a rich source of protein commonly consumed as an alternative source of protein due to the higher cost of meat and other sources of animal protein (Oluwaniyi and Dosumu, 2009). Fish has lower cholesterol content when compared with meat and thus often recommended for consumption especially among the adult population (Harris, 1997). The marine fish is generally cheaper and more abundant when compared with fresh water fishes, which are relatively more expensive in Nigeria (Oluwaniyi and Dosumu, 2009). Fish is a highly perishable food and so, many strategies have been developed to limit its spoilage (Gómez-Estaca et al., 2009). According to KumoluJohnson et al. (2010) various food preservation techniques have been utilized to improve the microbial safety and extend the shelf-life of fish in general including freezing, chemical preservation, salting, smoking, frying and filleting. However, smoking is the most popular method of fish processing (Bako, 2004). Food is considered to be microbiologically unsafe owing to the presence of microorganisms which may invade human body (e.g Salmonella, Escherichia coli, Listeria monocytogenes, etc) and also those that produce toxins ingested with a food such as Staphylococcus aureus, Clostridium botulinum and Bacilus cereus (Ofred, 2009). The growth of these pathogens may not necessarily results in food spoilage. Hence the absence of deleterious sensory changes cannot be used as an indicator for food microbiological safety (Border and Norton, 1997). Consequently many outbreaks are caused by bacteria originating in the animal/human reservoir including Salmonella, Shigella, E. coli, and Staphylococcus aureus, (Huss et al., 1997). Generally fish and shellfish are common vehicles of transmitting food borne diseases. It is known that the primary source of cholera is feces of infected persons and transmission of bacteria with water and food. However, at present it has also been found that in certain areas the aquatic environment is a natural reservoir (habitat) for Vibrio cholerae. Microbiologists are of the opinion that the presence of Escherichia coli in food indicates the probability of contamination of the food products with the sewage of human or animal origin (Ofred, 2009). Data on risk factors for foodborne diseases indicate 
that the majority of outbreaks result from inappropriate food handling practices (Jones and Angulo, 2006). Incidences of food borne disease outbreaks are been reported each year in Kenya (Githiri et al., 2009). However, there is scarcity of information on occurrences of pathogens on fish and other ready to eat food in Nigeria thus the need for this study with the objective of determining some microorganisms that are prevalent on smoked fish sold in markets in Ibadan Oyo State Nigeria.

\section{MATERIALS AND METHODS}

Sample Collection: 3 replicates of 4 different smoke dried fish including Mackerel (Scomber scombrus), Sardine (Sardinela eba), Panla (Gadus morhua) and Cat fish (Clarias gariepinus) were purchased from 5 different markets; OJoo, Apata, Iwo-road, Bodija and Omi-Adio, in Ibadan, Oyo state South-Western Nigeria (totaling 60 fishes). The fish samples were collected and kept in sterile polythene bags for microbial analysis.

Preparation of Materials: The working tables were swabbed with ethanol to disinfect them. All the wares were washed and air-dried after which they were sterilized in hot air oven at $160^{\circ} \mathrm{C}$ for 1 hour. Culture media like nutrient agar was prepared according to manufacturers' specifications and distilled water used for serial dilution was sterilized in an autoclave at $121^{\circ} \mathrm{C}$ for 15 minutes before use.

Preparation of agar plate: The agar plates were prepared by first sterilizing the petri dishes. This was done by putting the petri dishes in petri dish cans in the hot air oven at $160^{\circ} \mathrm{C}$ for 1 hour. The sterilized plates were then left in petri dish cans until required, the wire loop was sterilized by flaming in red-hot fire using a spirit lamp. The agar were prepared by dissolving $0.6 \mathrm{~g}$ of the agar in $100 \mathrm{ml}$ distilled water and the sterilize using a microwave at $121^{\circ} \mathrm{C}$ for $15 \mathrm{~min}$ and left to cool to $45^{\circ} \mathrm{C}$.

Preparation of fish samples for microbiological tests: Fish samples were collected in triplicates from the samples bought from different markets. The fish were minced after which serial dilution was made, total viable count was done, colonies on the plates were picked and sub-cultured and then identified.

Serial dilution: $10 \mathrm{~g}$ of each fish sample were weighed aseptically and homogenized in $90 \mathrm{ml}$ sterile peptone water. Then, serial dilutions was made by mixing $1.0 \mathrm{ml}$ of the suspension in $9.0 \mathrm{ml}$ sterile peptone water to obtain $10^{-1}$ dilution. The dilution was then made to $10^{-2}$, and $10^{-3}$ diluents, then spread-plated on plates of nutrient agar (for total viable counts); Salmonella- shigella agar (for Salmonella and Shigella species); Mannitol salt agar (for Staphylococcus spp); Listeria agar base (for Listeria monocytogenes); MacConkey agar (for E. coli and other enteric bacteria); Robertson cooked meat medium (for Clostridium botulinum) and Eosin Methylene blue agar (for enteric bacteria). The plates was triplicated and incubated at $37^{\circ} \mathrm{C}$ for 24 hours. Total number of cells per gram of samples were then estimated after counting the colonies on the plates. Colonies on the plates were then picked and sub-cultured on nutrient agar plates to ensure purity of cultures. The different pure cultures were then transferred to nutrient agar slopes and then identified.

Characterization and identification of the isolates: Bacterial isolates were characterized using routine microbiological procedures as described by Olutiola et al. (1991); Fawole and Osho (1995) after which they were identified using Bergey's Manual of Determinative Bacteriology. The microbiological identification procedures used include:

Colony morphology: This involve the microscopic evaluation of the characteristics of bacteria colonies on the agar plates. The characteristics considered include the shape of the colony, elevation of the colony, edge of the colony, colony surface pigmentation and the optical characteristics.

Cell morphology: This shall involve staining of the isolates to show the cell shape and appearance. In this study, gram staining method was carried out on each isolate. This involve studying the isolates under the oil lens immersion microscope after gram-staining. A thin smear of each isolate was made and heat-fixed. The heat-fixed smears was covered with crystal violet for about 1 minute and immediately rinsed with clean water. The smear was then flooded with iodine for 1 minute and then rinse immediately. The smear was then decolorized for $10-30 \mathrm{sec}$ using $95 \%$ ethyl alcohol. Alcohol action was terminated by rinsing the slide with clean water, then the smear was counterstained with safranin for 30 seconds and then it was rinsed off using clean water and after which it was allowed to air dry. The stained slides were examined under the microscope (with the aid of immersion oil) for results. Gram-positive organisms appeared in purple while gram-negative organisms appeared in pink or red.

Motility test: This was carried out using hanging drop method (Fawole and Osho, 1995). Here, a clean depression slide and cover glass was used, they were washed and rinsed to provide a grease-free slide. Then a very small amount of Vaseline was placed near each corner of the cover slide. Two loopful of the isolate 
were placed in contact with the cover glass with the depression slide put over the drop of suspended bacteria. The slide was quickly inverted and examined under the microscope, then the motion of the organisms were observed.

Biochemical Test: Some of the biochemical test carried out include: catalase test, indole test, citrate test sugar fermentation test and oxidase test.

Statistical Analysis: The results are expressed as means and standard deviation and analysed using two ways analysis of variance (randomized complete block design) using SPSS version 17.0 where significant difference $(\mathrm{p}<0.05)$ recorded. Duncan multiple range test was used to separate the means.

\section{RESULTS AND DISCUSSION}

The microbial load on fish from different market locations in Ibadan metropolis are presented in Figure 1. The highest bacteria load was recorded on fish samples from Ojo market followed by those from Apata market while the lowest bacterial count was recorded on fish samples from Bodija market.

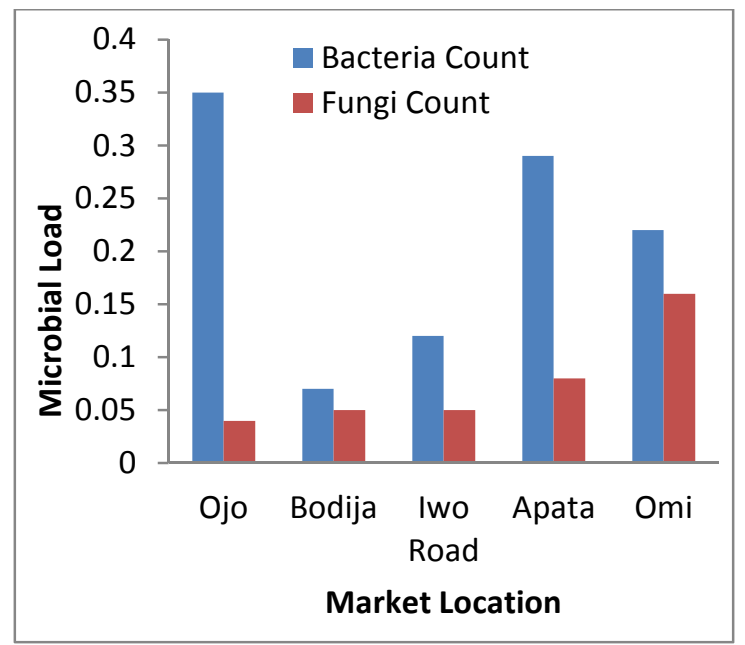

Fig 1: Microbial Load on Fish from Different Market Location in Ibadan Oyo state

The result in table 1 show that the highest fungi count was recorded on fish samples from Omi market $(0.05 \pm$ $0.07 \times 10^{3} \mathrm{CFU} / \mathrm{g}$ ) followed by those samples from Apata market $\left(0.04 \pm 0.07 \times 10^{3} \mathrm{CFU} / \mathrm{g}\right)$ while the lowest fungi count was recorded on fish samples from Ojo market $\left(0.16 \pm 0.10 \times 10^{3} \mathrm{CFU} / \mathrm{g}\right)$. The highest bacterial load on different fish types within Ibadan metropolis as presented on figure 2 was recorded on Panla (Gadus morhua) with the value $0.27 \pm 0.19 \times 10^{3}$ $\mathrm{CFU} / \mathrm{g}$, followed by sardine (Sardinela eba) with value $0.27 \pm 0.19 \times 10^{3} \mathrm{CFU} / g$ while the lowest bacteria count was recorded on catfish (Clarias gariepinus) samples with value $0.14 \pm 0.10 \times 10^{3} \mathrm{CFU} / \mathrm{g}$. Also, represented in figure 2 was the fungi load on different fish types in Ibadan metropolis. The highest fungi count of $0.09 \pm 0.07 \times 10^{3} \mathrm{CFU} / \mathrm{g}$ was recorded on sardine (Sardinela eba) followed by $0.08 \pm 0.12^{\mathrm{a}} \times 10^{3}$ $\mathrm{CFU} / \mathrm{g}$ recorded for catfish (Clarias gariepinus) and Panla (Gadus morhua) while the lowest fungi count of $0.06 \pm 0.04 \times 10^{3} \mathrm{CFU} / \mathrm{g}$ was recorded Mackerel (Scomber scombrus). However, there is no significant difference $(\mathrm{P}>0.05)$ on the microbial load of the different fish species sold in Ibadan metropolis.

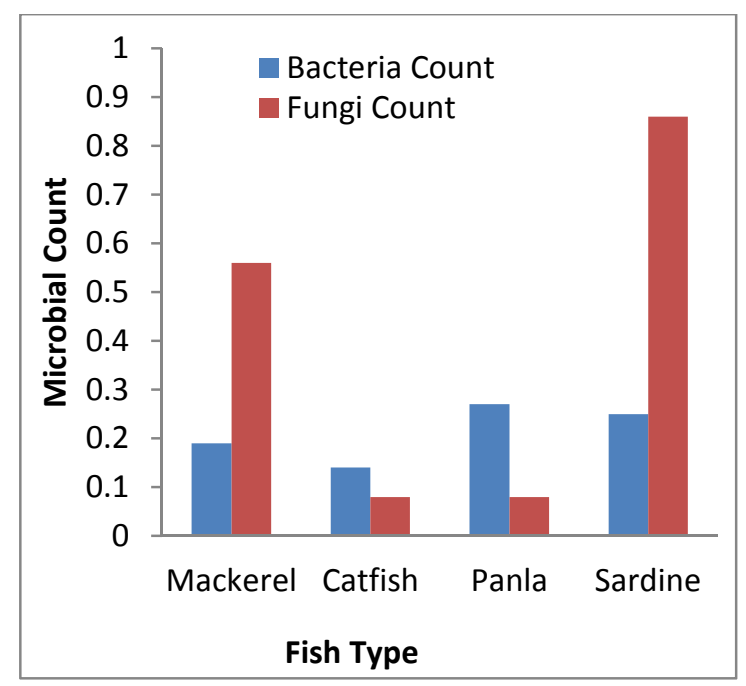

Fig 2: Microbial Count on Different Fish Type in Ibadan Oyo State

Table 1: Microbial Load on Fish from Different Market

\begin{tabular}{lll} 
& \multicolumn{2}{c}{ Location in Ibadan } \\
\hline Market & TVC $($ Cfu/g) & Fungi $($ Cfu/g) \\
\hline Ojo & $0.35 \pm 0.11^{\mathrm{a}} \times 10^{3}$ & $0.16 \pm 0.10^{\mathrm{a}} \times 10^{3}$ \\
Bodija & $0.07 \pm 0.04^{\mathrm{a}} \times 10^{3}$ & $0.05 \pm 0.07^{\mathrm{a}} \times 10^{3}$ \\
Iwo-road & $0.12 \pm 0.10^{\mathrm{a}} \times 10^{3}$ & $0.08 \pm 0.05^{\mathrm{a}} \times 10^{3}$ \\
Apata & $0.30 \pm 0.20^{\mathrm{a}} \times 10^{3}$ & $0.04 \pm 0.07^{\mathrm{a}} \times 10^{3}$ \\
Omi & $0.22 \pm 0.32^{\mathrm{a}} \times 10^{3}$ & $0.05 \pm 0.07^{\mathrm{a}} \times 10^{3}$ \\
SEM & 0.04 & 0.02
\end{tabular}

Column mean with the same superscript are not significantly different $(p>0.05)$

Table 2: Microbial count different fish species sampled

\begin{tabular}{lll}
\hline Fish spp & TVC $($ Cfu/g) & Fungi $($ Cfu/g) \\
\hline Mackerel & $0.19 \pm 0.22^{\mathrm{a}} \times 10^{3}$ & $0.06 \pm 0.04^{\mathrm{a}} \times 10^{3}$ \\
Catfish & $0.14 \pm 0.10^{\mathrm{a}} \times 10^{3}$ & $0.08 \pm 0.12^{\mathrm{a}} \times 10^{3}$ \\
Panla & $0.27 \pm 0.19^{\mathrm{a}} \times 10^{3}$ & $0.08 \pm 0.71^{\mathrm{a}} \times 10^{3}$ \\
Sardine & $0.25 \pm 0.20^{\mathrm{a}} \times 10^{3}$ & $0.09 \pm 0.07^{\mathrm{a}} \times 10^{3}$ \\
SEM & 0.04 & 0.02 \\
\hline
\end{tabular}

Column mean with the same superscript are not significantly different $(P>0.05)$

The result of this study (table 1) indicate that there is no significant difference $(\mathrm{P}>0.05)$ on the microbial load of fish sampled in the different market location meaning that the fish sold in different markets in Ibadan Oyo state have similar microbial load which still fall within the recommended microbial limit in the guidelines for the microbiological quality of various 
ready-to-eat foods by Gilbert (2000) and Taoukis et al. (1999) that is the fish sold in the various markets in Ibadan is fit for human consumption. The microbial load on the various fish spp still fall within the recommended microbial limit in the guidelines for the microbiological quality of various ready-to-eat foods by Gilbert (2000) and Taoukis et al. (1999). Result obtained from the study showed that Aspergillus flavus, Geotricium albidium, Trichoderma sp., Fusarum oxysporium, Penicillium spp, Aeromonas spp, Klebsiella oxytoca, Levinae spp, Serratia rubidaea, Proteus vulgaris, Shigella flexneri, Enterobacter aerogenes, Vibrio cholerae, Escherichia coli, Salmonella arizonae, Streptobacillus monilliforms, Bacteria necrophorus, Pseudomonas amattophillia and Chromobacterium violeceum, are the microorganisms found to be associated with smoke dried fishes sold in different market in Ibadan. The presence of all these bacteria and fungi may make its consumption hazardous to health as some of these microorganisms have been reported by other authors has been hazardous for human consumption. Fawole and Osho (1995) reported that Spoilage of fish is mainly due to the activity of psychrotrophic gramnegative bacteria such as Shewanella putrefaciens and Pseudomonas spp. Akande and Tobor (1999) also reported that fish and fish products spoil by different specific spoilage organisms (SSO) depending on the final treatment or preservation and storage temperature. Examples of SSO in different fish and fish products include Pseudomonas, Shewanella putrefaens, Photobactereum phosporeum, Aeromonas hydrophila, and Alteromonas putrefaciens, Vibrionaceae, Aeromodans, Moraxella, Acinetobacter, Enterobacteriaceae; and Yeast and molds. According to Ayeloja et al. (2011), in artisanal fishery, freshly caught fish are covered with damp sacks and at times they are mixed with wet grass or water weeds to reduce the temperature. Fish treated this way is prone to contamination with microorganisms such as Salmonella and Aspergillus. This indicates that spoilage of fish starts right from the aquatic ecosystem. Processed fishes are also prone to microbial attack especially in artisanal fishery due to unhygienical method of processing and preservation. During the smoke drying period, smoking kilns used in artisanal fishery and overloading of the fishes on the trays lead to improper processing which in turns encourage fungal attack. During storage of smoked dried fish product, good storage practices are not adhered to by fish mongers hence stores are not well ventilated and pest can easily gain access into the stores. The environment in which fishes are displayed in the market is not always hygienic and this is another avenue for microbial contamination very often, retailers' display the smoke dried fish sample in open trays beside the gutter or refuse heaps, this also encourages fungi and bacteria attack and subsequent production of toxins. This is an agreement with the report of Ayeloja et al. (2011).

Conclusion: The study revealed that smoked-dried fishes in Omi, Iwo Road, Bodija, Ojoo and Apata markets in Ibadan Oyo State are contaminated with micro-organisms. However, the microbial load still fall within the recommended microbial limit for readyto-eat foods indicating that the fish sold in different markets within Ibadan metropolis is fit for human consumption. The microbial load on different fish spp in Ibadan metropolis are not significantly different ( $\mathrm{p}$ $>0.01$ ) from each other. It is therefore recommended that fish stores should be well screened and ventilated so as to avoid contamination of smoked fish products.

\section{REFERENCES}

Oluwaniyi, OO; Dosumu, OO (2009). Preliminary Studies on the effect of processing methods on the quality of three commonly consumed marine fishes in Nigeria. BIOKEMISTRI. 21 (1): 1-7.

Harris, WS (1997). N-3 fatty acids and serum lipoproteins: human studies. Amer. J. Clinical Nutri. 65:1645-1654.

Gómez-Estaca, AJ; López, D; Lacey, MC; GómezGuillén, ME; López-Caballero; Montero, P (2009). Antimicrobial Activity of Composite Edible Films Based on Fish Gelatin and Chitosan Incorporated with Clove Essential Oil. Journal of Aquatic Food Product Technology. 18 (2): 46-52.

Kumolu-Johnson, CA; Aladetohun, NF; Ndimele PE (2010). The effects of smoking on the nutritional qualities and shelf-life of Clarias gariepinus (BURCHELL 1822). Afr. J. Biotechnol. 9: 73 -76.

Bako, WS (2005). The role of women in fish processing: Handling and marketing in Kainji Lake basin. Proceedings of $19^{\text {th }}$ Annual Conference of the Fisheries Society of Nigeria (FISON), Nov. 29 - Dec. 3, 2004, Ilorin, Nigeria.

Ofred, JMM (2009) Microbiology and Spoilage Trail in Nile Perch (Lates niloticus), Lake Victoria, Tanzania. A thesis submitted for a partial fulfilment of the requirement for the degree of Masters of Science in Food Science (Seafood Processing) Faculty of Food Science and Nutrition, School of Health Sciences University of Iceland Reykjavik, ICELAND. Pp94. 
Border, P and Norton, M (1997). Safer eating: microbiological food poisoning and its prevention. The Parliamentary Office of Science and Technology, London.

Huss, H; Dalgaard, P and Gram, L (1997). Microbiology of fish and fish products. In Luten J. B., Borresen T., and Oihlenschlager J., (1997): Seafood from producer to consummer, intergrated approach to quality. Development in food science 38. Proceedings of the International Seafood Conference on the occasion of the 25th anniversary of the WEFTA, held in Noordwijkerhout, The Netherlands, 13-16 November.

Jones, TF; Angulo, FJ (2006). Eating in Restaurants: a risk factor for food borne disease. J. Clinical Infection Diseases. 43: 1324 -1328.

Githiri, M; Okemo, $\mathrm{P}$ and Kimiywe, J (2009). Hygienic practices and occurrence of coliforms and Staphylococcus on food at a public hospital in Kenya. J. Appl. Biosciences. 27: 1727 - 1731.

Olutiola, PO; Famurewa, O; Sonntag, HG (1991). An introduction to General Microbiology: A Practical Approach. Heidelberger Verlagsanslait Druckerei, Heidelberg Germany. Pp112 - 175.

Fawole, MO and Osho, BA (1995). Laboratory manual of microbiology. Shalom prints Ibadan Nigeria. Pp25 - 30 .
Centre for Food Safety Food and Environmental Hygiene Department (CFSFEHD) (2007). Microbiological Guidelines for Ready-to-eat Food. Risk Assessment Section Centre for Food Safety Food and Environmental Hygiene Department, Hong Kong. 15pp.

Gilbert, RJ (2000). Microbiological Guidelines for Ready-to-Eat Foods. Food watch, western Australian food monitoring program. Pp5.

Taoukis, PS; Koustsoumsnis, K; Nychas, GJE (1999). Modelling of spoilage microflora of boque (oops boops) as a bases for chilled distribution monitoring with time -temperature indicators. In Bourgeois, C. M, Roberts T. A. (Eds.), Predictive microbiology applied to chilled food preservation (Proceedings of the international Symposium, Quimper, France, June 16-18, 1997). Refrigeration Science and Technology Proceedings series, International Institute of Refrigeration (IIR), Paris, France. Pp316-325.

Akande, GR and Tobor, JG (1992). Improved utilization and increased availability of fishing products as an effective control of aggravated animal protein deficiency induced malnutrition in Nigeria proceedings of the $10^{\text {th }}$ annual conference of the fisheries society of Nigeria. Pp18-31.

Ayeloja, AA; George, FOA; Obasa, SO; Sanni, LO; Ajayi, AA (2011). Effects of length of delay after slaughter (LODAS) on raw catfish Clarias gariepinu. J. Amer. Sci. 7 (6): 508 - 512. 